\title{
Artikel
}

\section{De retoriek van gun-jumping}

\author{
Stijn de Jong*
}

De Europese Commissie straft overtredingen van de fusiecontroleregels de laatste tijd hard af. Dat geldt voor het aanleveren van incorrecte informatie, ${ }^{1}$ maar ook voor het zonder goedkeuring implementeren van meldingsplichtige concentraties (ook wel: 'gun-jumping'). Zo waarschuwde Eurocommissaris Vestager:²

'And we need companies to wait until they have our OK, before they start to put a merger into effect. Because otherwise, the harm to competition could already be done, before we have the chance to intervene. So if they jump the gun, we take that very seriously indeed.'

We kunnen deze retoriek vergelijken met de situatie in de Verenigde Staten rond 2000. De Amerikaanse mededingingsautoriteiten traden toen ook hard op tegen gunjumping. Het effect was dat bedrijven veiligheidshalve ook procompetitief gedrag stopten, mede gezien de onduidelijke reikwijdte van de verbodsbepalingen. Als reactie op deze dynamiek hield William Blumenthal, General Counsel van de Federal Trade Commission, in 2005 een relativerende speech met de titel 'The Rhetoric of Gun-Fumping' 3 Zijn conclusie: er mag meer dan iedereen denkt en voor het commercieel slagen van transacties is het juist noodzakelijk dat partijen veel informatie uitwisselen en de implementatie grondig voorbereiden.

De vraag is of de geschiedenis zich herhaalt. Treden de ACM en de Commissie enkel op tegen overduidelijke overtredingen of wordt ook mededingingsbevorderend gedrag afgeschrikt? Is er behoefte aan 'reset' van de retoriek? Ter begrenzing van het onderwerp behandel ik enkel de zaken die na 2007 zijn uitgekomen, dus na het laatste overzichtsartikel over gun-jumping in dit tijdschrift. ${ }^{4}$ Vooraf bespreek ik de definitie van gun-jumping en de mogelijke gevolgen van een overtreding.

\section{Wat is gun-jumping?}

De term gun-jumping is veelomvattend en kan tot verwarring leiden. In de praktijk wordt de term gebruikt om drie verschillende overtredingen van de mededingingsregels aan te duiden:

1. Overtreding van de meldingsplicht. Op grond van artikel 4 lid 1 van de Concentratieverordening ${ }^{5}$ moet een concentratie met een communautaire dimensie bij de Commissie worden aangemeld vóór de totstandbrenging ervan. Dat is een positieve verplichting: partijen moeten actief handelen en de voorgenomen concentratie melden. Het Nederlandse equivalent van deze meldingsplicht staat in artikel 34 Mededingingswet $(\mathrm{Mw})$.

2. Overtreding van de standstillverplichting. Op grond van artikel 7 lid 1 Concentratieverordening mag een beoogde concentratie niet tot stand worden gebracht totdat deze (simpel gezegd) goedgekeurd is door de Commissie. Dat is een negatieve verplichting: partijen mogen niet implementeren voor goedkeuring.
4. E.J. Poelman, 'Gun-jumping: averij in het zicht van de haven', M\&M 2007/3, p. 68-76.

5. Verordening (EG) nr. 139/2004 van de Raad van 20 januari 2004 betreffende de controle op concentraties van ondernemingen, $P b E U$ 2004, L 24/1 (Concentratieverordening). 
Voor Nederland staat dit verbod ook in artikel 34 Mw. ${ }^{6}$

3. Overtredingen van artikel 6 lid $1 \mathrm{Mw}$ of artikel 101 lid 1 VWEU in de context van een voorgenomen concentratie. Het uitwisselen van concurrentiegevoelige informatie tijdens een transactieproces kan de mededinging beperken, bijvoorbeeld als concurrenten bespreken welke prijzen zij rekenen aan individuele klanten.

Het is belangrijk onderscheid te maken tussen deze vormen van gun-jumping. Zo verschillen de normadressaten (bij de meldingsplicht en standstillverplichting is dat enkel de onderneming die zeggenschap verkrijgt, bij het kartelverbod beide partijen) en de periode waarin partijen rekening moeten houden met deze regels (de standstillverplichting geldt niet meer nadat de concentratie is goedgekeurd, terwijl het kartelverbod van toepassing is tot zeggenschap over de doelvennootschap daadwerkelijk is overgedragen). ${ }^{7}$ Vooral dat laatste verschil leidt soms tot verwarring: bij transactiepartijen ontstaat gemakkelijk het beeld dat zij na goedkeuring onbeperkt informatie mogen uitwisselen. Ook bestaan aanzienlijke verschillen tussen de Nederlandse en Europese regels. De belangrijkste noem ik hierna. ${ }^{8}$

\section{Maximale boetes}

De Commissie kan een geldboete van maximaal 10 procent van de totale jaaromzet van de betrokken onderneming opleggen. ${ }^{9}$ Dat boetemaximum geldt ook bij recidive. Hoewel een overtreding van de meldingsplicht van artikel 4 lid 1 Concentratieverordening impliceert dat ook de standstillverplichting van artikel 7 lid 1 Concentratieverordening is overtreden, ${ }^{10}$ kan de Commissie in zo'n situatie toch twee boetes opleggen: één voor overtreding van elk afzonderlijk artikel. ${ }^{11}$

Omdat de meldingsplicht en de standstillverplichting in Nederland zijn samengevoegd in één artikel, kan de Autoriteit Consument \& Markt (ACM) voor overtreding daarvan slechts één boete opleggen. Die boete is

6. CBb 24 februari 2012, ECLI:NL:CBB:2012:BV6874 (Pacton), r.o. 5.3 'Het standpunt van NMa dat artikel $34 \mathrm{Mw}$ geen meldingsplicht bevat, maar alleen een verbod van voortijdige totstandbrenging van een concentratie, volgt het College niet. Dit artikel houdt blijkens de tekst twee verplichtingen in: de verplichting een voorgenomen concentratie aan te melden en de verplichting om vervolgens vier weken te wachten alvorens de concentratie tot stand te brengen.'

7. Daarnaast is art. 6 lid $1 \mathrm{Mw}$ ook van toepassing als de concentratie niet meldingsplichtig is.

8. Ik besteed daarbij geen aandacht aan art. 6 lid 1 Mw en art. 101 lid 1 VWEU.

9. Art. 14 lid 2 Concentratieverordening.

10. Het tegenovergestelde geldt niet: een onderneming kan art. 7 lid 1 Concentratieverordening overtreden zonder art. 4 lid 1 Concentratieverordening te overtreden door een concentratie te implementeren na melding daarvan, maar vóór goedkeuring.

11. Gerecht 26 oktober 2017, zaak T-704/14, Marine Harvest, ECLI:EU:T 2017:753, r.o. 306, waar het Gerecht dit rechtskader 'ongebruikelijk' noemt omdat 'er twee artikelen in verordening nr. 139/2004 staan waarvan de schending kan leiden tot geldboeten van eenzelfde strafmaat, maar waarvan schending van de eerste noodzakelijkerwijs leidt tot schending van de tweede.' Dat leidt volgens het Gerecht echter niet tot het schending van het beginsel van 'eendaadse samenloop' of 'ne bis in idem' (r.o. 292-374) maximaal 10 procent van de totale jaaromzet, tenzij in de vijf jaar voor de dagtekening van het boeterapport een boete voor een soortgelijke overtreding onherroepelijk is geworden. In dat geval kan de ACM de boete met 100 procent verhogen. ${ }^{12}$

\section{Feitelijk leidinggeven}

De Commissie kan geen boetes opleggen aan natuurlijke personen voor overtredingen van de meldingsplicht of de standstillverplichting. De ACM kan dat wel, via de constructie van feitelijk leidinggeven. ${ }^{13}$ Daarvan zijn mij echter geen voorbeelden bekend.

\section{Verjaring}

Het Europese regime kent verschillende verjaringstermijnen. Een overtreding van de meldingsplicht van artikel 4 lid 1 Concentratieverordening is een 'instantaneous infringement', waarvoor een verjaringstermijn van drie jaar geldt die aanvangt op de dag waarop de concentratie is geimplementeerd. ${ }^{14}$ Dat geldt niet voor een inbreuk op de standstillverplichting. Dat is een 'infraction continue', waarvoor een verjaringstermijn van vijf jaar geldt die aanvangt op de dag dat inbreuk is beëindigd. ${ }^{15}$ Een inbreuk op artikel 7 lid 1 Concentratieverordening eindigt pas wanneer de concentratie is goedgekeurd door de Commissie, afstand is gedaan van zeggenschap of een ontheffing is verkregen. ${ }^{16}$ Dat heeft het verstrekkende gevolg dat een onderneming die meer dan vijf jaar geleden zonder goedkeuring een concentratie met een communautaire dimensie heeft geïmplementeerd, nog steeds beboet kan worden. ${ }^{17}$

De boetebevoegdheid van de ACM voor een overtreding van artikel $34 \mathrm{Mw}$ vervalt vijf jaar nadat de overtreding heeft plaatsgevonden. ${ }^{18}$ De Nederlandse beschikkingenpraktijk veronderstelt dat een overtreding van artikel $34 \mathrm{Mw}$ geen duur kent, omdat de overtreding plaatsvindt op het moment dat de concentratie wordt geimplementeerd zonder voorafgaande melding c.q. goedkeuring. ${ }^{19}$ Dat betekent dat de boetebevoegdheid van de ACM vijf jaar na implementatie van de concentratie vervalt.

Consequenties voor de concentratie

De Commissie kan definitieve of voorlopige passende maatregelen nemen wanneer een concentratie vroegtijdig is geimplementeerd. Daartoe behoort ook een bevel

12. Art. 74 lid 1 en $2 \mathrm{Mw}$.

13. Vgl. Besluit NMa 14 juli 2010, zaak 1528/894 (Wegener), waar de NMa een boete oplegde aan vijf leidinggevenden vanwege het nietnaleven van voorschriften bij een concentratie.

14. Art. 1 lid 1 sub a Verordening (EEG) nr. 2988/74. Zie ook Besluit Europese Commissie 23 juli 2014, zaak M.7184 (Marine Harvest), par. 128.

15. Art. 1 lid 1 sub $b$ in samenhang met art. 1 lid 2 Verordening (EEG) nr. 2988/74. Zie ook HvJ EU 3 juli 2014, zaak C-84/13, Electrabel, ECLI:EU:C:2014:2040, r.o. 52.

16. Gerecht 26 oktober 2017, zaak T-704/14, Marine Harvest, ECLI:EU:T: 2017:753, r.o. 562. Een ontheffing kan worden verkregen op grond van art. 7 lid 3 Concentratieverordening.

17. P. Honoré en G. Vatin, 'The French Competition Authority's Altice Decision: Record Fine for the First 'Genuine' Gun Jumping Case in Europe', JCLAP 2017, vol. 8, nr. 5.

18. Art. 34 en 74 lid $1 \mathrm{Mw}$ in samenhang met art. 5:45 en 5:53 Awb.

19. Besluit NMa 28 maart 2013, zaak 7491 (Motorhuis), par. 55. 
tot ontbinding van de concentratie. ${ }^{20}$ De ACM kan een last onder dwangsom opleggen met daaraan gekoppeld de verplichting voor een onderneming de concentratie te ontbinden. ${ }^{21}$ Noch de Commissie noch de ACM heeft ooit van deze mogelijkheid gebruikgemaakt. Vestager merkte hierover het volgende op: ${ }^{22}$

'It is an extreme step to undo a merger approval but I don't think that one can completely say that it will never happen (...) It will have to be a very, very, very severe infringement of our procedural rules that has real effects in the market concerned if we were ever to take the step of withdrawing a merger clearance.'

Een andere vraag is wat de civielrechtelijke consequenties zijn van een overtreding van de meldingsplicht of standstillverplichting. Volgens de Concentratieverordening is de geldigheid van transacties die in strijd met de standstillverplichting tot stand komen afhankelijk van de uiteindelijke uitkomst van de concentratiebeoordeling. ${ }^{23}$ De Nederlandse situatie is lastiger. De memorie van toelichting bij de Mw suggereert dat rechtshandelingen die een concentratie tot stand brengen in strijd met artikel $34 \mathrm{Mw}$ nietig zijn op grond van artikel 3:40 lid $2 \mathrm{BW}^{24}$ De vraag is of dat nog past bij de meer genuanceerde benadering van nietigheid die volgt uit recente uitspraken van de Hoge Raad. ${ }^{25}$ Een overtreding van de meldingsplicht lijkt mij niet dermate ernstig dat nietigheid van de transactie altijd zou moeten volgen. Vergelijk daarbij de rechtspraak omtrent rechtshandelingen die strijdig zijn met het staatsteunverbod van artikel 108 lid 3 VWEU, waarbij nietigheid enkel volgt indien dat kan leiden tot herstel van de oude mededingingssituatie. ${ }^{26}$ Verdedigbaar is dat een niet-gemelde concentratie enkel nietig is als de concentratie mededingingsbeperkende effecten veroorzaakt. Echter, zelfs dan is het de vraag of alle partijen zich op deze nietigheid kunnen beroepen. ${ }^{27}$

Als een rechtshandeling nietig is wegens strijd met artikel $34 \mathrm{Mw}$, wordt deze op grond van artikel 3:58 lid 1 BW wel bekrachtigd (geconvalesceerd) als de ACM de

20. Art. 8 lid 4 en 5 Concentratieverordening.

21. Art. 74 lid 1 sub 5 onder b Mw. De plicht om de concentratie te ontbinden kan in specifieke omstandigheden ook rechtstreeks voortvloeien uit de wet (art. 39 lid 2 sub a, art. 40 lid 3 sub a en art. 46 lid 3 Mw).

22. Nieuwsbericht van Parr Global op 6 juli 2017, 'Vestager says merger clearance withdrawal possible if procedural infringements extreme'.

23. Art. 7 lid 4 Concentratieverordening. Dat artikel tast echter niet de geldigheid aan van effectentransacties, tenzij de kopers en de verkopers 'wisten of dienden te weten' dat de transacties in strijd waren met de standstillverplichting.

24. Kamerstukken II 1995/96, 24707, 3 (MvT), p. 77.

25. HR 1 juni 2012, ECLI:NL:HR:BU5609, NJ 2013, 172 m.nt. T.F.E. Tjong Tjin Tai (Esmilo/Mediq Apotheken) (hoewel in de context van art. 3:40 lid $1 \mathrm{BW}$ ).

26. HR 27 mei 2016, ECLI:NL:HR:2016:994, NJ 2017, 295 (Commerz) Havenbedriff), r.o. 3.8.2

27. Zie over de vraag of het effect van een wetsbepaling die tot nietigheid leidt door de werking van de redelijkheid en billijkheid kan worden beperkt: A.S. Hartkamp, 'Nietigheid en de beperkende werking van redelijkheid en billijkheid', in: S.E. Bartels, C.J.H. Jansen, B.A. Schuijling en N.S.G.J. Vermunt (red.), Vertrouwen in het burgerlijke recht. Liber amicorum prof. mr. S.C.J.J. Kortmann, Deventer: Wolters Kluwer 2017. concentratie goedkeurt. ${ }^{28}$ Uit Tatra Wood volgt dat convalescentie niet mogelijk is als een van de 'onmiddellijk belanghebbenden' in het tijdvak tussen het verrichten van de rechtshandeling en de vervulling van een voor haar geldigheid gesteld wettelijk vereiste zich 'op de nietigheid [heeft] beroepen of zich [heeft] gedragen op een wijze die onverenigbaar is met de geldigheid van de desbetreffende rechtshandeling.' 29 Dat roept de vraag op wie de 'onmiddellijk belanghebbenden' zijn die zich op de nietigheid kunnen beroepen vóór goedkeuring door de ACM. Naar mijn idee zijn dat in ieder geval de bij de concentratie betrokken partijen (zij het dat deze mogelijkheid beperkt kan zijn door de redelijkheid en billijkheid). ${ }^{30}$ Uit de wetsgeschiedenis volgt dat het begrip 'onmiddellijk belanghebbenden' onder omstandigheden ruimer kan worden geïnterpreteerd. ${ }^{31}$ Het gaat naar mijn mening echter te ver om concurrenten te rekenen tot de kring van partijen die een bekrachtiging door de ACM kunnen verhinderen door vóór goedkeuring een briefje naar contractpartijen te sturen met de boodschap dat de concentratie nietig is wegens strijd met artikel 34 Mw. Dat een (potentiële) concurrent belanghebbende kan zijn in een beroep tegen een goedkeuringsbesluit doet daar niet aan af. ${ }^{32}$

Een complexe situatie doet zich voor als een concentratie zonder communautaire dimensie in meerdere lidstaten is geimplementeerd, waarbij in verschillende lidstaten een meldingsplicht of standstillverplichting is overtreden. Wanneer partijen in Nederland procederen over de geldigheid van de concentratie, zal de rechter eerst aan de hand van de Rome I Verordening moeten vaststellen welk recht op de relevante koop- of fusieovereenkomst van toepassing is. ${ }^{33}$ Vaak hebben partijen een rechtskeuze gemaakt. ${ }^{34}$ Vervolgens moet de rechter bepalen of de overtreden buitenlandse regels bepalingen van bijzonder dwingend recht zijn in de zin van artikel 9 Rome I Verordening, zodat de aangezochte rechter daar - ondanks de rechtskeuze - toch rekening mee kan houden. Als de rechter dat niet doet, liggen mogelijk tenuitvoerleggingsperikelen op de loer in de lidstaat waar de standstillverplichting is geschonden. ${ }^{35}$ In ieder geval moeten partijen in dit scenario rekening houden met handhavingsacties van de relevante nationale mededingingsautoriteiten.

Het verdient aanbeveling om in de transactiedocumentatie rekening te houden met de gevolgen van een onverhoopte overtreding van een meldingsplicht. Denk daar-

28. Kamerstukken II 1995/96, 24707, 3 (MvT), p. 77. Zie ook Rb. Rotterdam 28 juni 2012, ECLI:NL:RBROT:2012:BW9829 (Amlin), r.o. 5.7 Anders: S.J. van der Voorde, 'Verkerk-Horn, zaaknr. 1774', M\&M 2000/6, p. 234-235.

29. HR 28 november 2014, ECLI:NL:HR:2014:3460, NJ 2016, 90 m.nt. H.J. Snijders (Tatra Wood), r.o. 3.6.2.

30. Zie voetnoot 28.

31. MvA II Inv., Parl. Gesch. Inv., p. 1175.

32. Rb. Rotterdam 27 juli 2017, ECLI:NL:RBROT:2017:5738 (Staatsloterij/ Lotto).

33. Art. 10 Verordening (EG) nr. 593/2008 (Rome I Verordening).

34. Art. 3 Rome I Verordening.

35. Art. 46 in samenhang met art. 45 lid 1 sub a Verordening (EU) nr. 1215/2012 (Brussel I Verordening (Herschikt)). 
bij aan het tijdelijk 'parkeren' van de activa die effect hebben op de markt waar niet gemeld is ${ }^{36}$ of een verplichting tot overleg c.q. heronderhandeling als de concentratie met nietigheid wordt bedreigd. Hoewel het debat over de toelaatbaarheid van contractuele conver$\mathrm{sie}^{37}$ in het geval van nietigheid op grond van artikel 6 lid $2 \mathrm{Mw}$ nog niet is uitgekristalliseerd, lijkt een dergelijke conversieclausule in het geval van nietigheid wegens overtreding van artikel $34 \mathrm{Mw}$ verdedigbaar. ${ }^{38}$

\section{Nederlandse zaken}

De meeste Nederlandse zaken zijn rechttoe rechtaan: partijen implementeerden een concentratie die vooraf niet was gemeld. In die zaken valt weinig eer te behalen aan het betwisten van de overtreding. De argumenten zullen zich valk toespitsen op boeteverlagende omstandigheden. Soms zorgt een zaak echter voor een kleine aardverschuiving: sinds de Pacton-zaak is duidelijk dat alleen de partij die zeggenschap verkrijgt beboet kan worden. ${ }^{39}$ Het valt op dat er geen recente Nederlandse boetes opgelegd zijn voor overtreding van artikel 34 Mw. Zoals vaker in het mededingingsrecht is het moeilijk vast te stellen wat de afwezigheid van meer recente boetebesluiten veroorzaakt: houden alle partijen zich aan de regels of worden overtredingen niet opgespoord?

Van Kerkhof \& Visscher-Renault

Van Kerkhof, een autodealer, tekende op 29 juni 2006 een koopovereenkomst voor een deel van de activiteiten van Renault Rotterdam. ${ }^{40}$ In deze overeenkomst stond het volgende: 'Koper verplicht zich om voorafgaande aan de datum van overdracht een melding te hebben gedaan aan de daartoe bevoegde autoriteit met betrekking tot de wetgeving op het gebied van Mededinging/ Concentratie.' Ondanks deze bepaling verkreeg Van Kerkhof op 1 juli 2006 zeggenschap. Toen Van Kerkhof twee dagen daarna de NMa informeerde over de transactie, startte de NMa een onderzoek en werd een boete opgelegd aan zowel de koper als verkoper. Om deze situatie te voorkomen is het gebruikelijk dat partijen een

36. 'Carve-out' constructies, waarbij partijen afspreken een concentratie te implementeren behalve in bepaalde jurisdicties omdat daar nog geen mededingingsrechtelijke goedkeuring is verkregen, zijn wel risicovol. Vgl. persbericht CADE 21 januari 2016, 'Cisco and Technicolor admit practice of gun jumping in global transaction'.

37. Wettelijke conversie van een concentratie die nietig is wegens strijd met art. $34 \mathrm{Mw}$ lijkt niet mogelijk (HR 18 december 2009, ECLI:NL:HR: 2009:BJ9439, NJ 2010, 140 (Prisma), r.o. 3.7.1)

38. De argumenten vóór en tegen contractuele conversie bij de nietigheidssanctie van art. 6 lid 2 Mw zijn ook relevant in het kader van nietigheid op grond van art. $34 \mathrm{Mw}$. Beide artikelen streven dezelfde doelstelling na: het beschermen van de mededinging op de Nederlandse markt (art. 6 lid $1 \mathrm{Mw}$ ex post en art. $34 \mathrm{Mw}$ ex ante). Zie over de toelaatbaarheid van conversieclausules: T.H.M. van Wechem, 'Boiler Plates etc. Is de nietigheidsecarterende (en/)of conversieclausule (severability clause) eigenlijk wel toegestaan?', Contracteren 2017, nr. 1, p. 14

39. CBb 24 februari 2012, ECLI:NL:CBB:2012:BV6874, NJB 2012/794 (PaCton).

40. Besluit NMa 29 juni 2007, zaak 5700/60 (Van Kerkhof \& VisscherRenault). voorwaarde in de transactiedocumentatie opnemen die de overdracht van zeggenschap opschort totdat goedkeuring is verkregen.

\section{HAL Investments}

Ook in deze zaak zijn de feiten simpel: HAL Investments verkreeg uitsluitende zeggenschap over Delta Wines, terwijl deze concentratie niet was gemeld. ${ }^{41}$ Koper en verkoper betaalden boetes tussen de 15.000 en 16.000 euro, waarbij in aanmerking was genomen dat zij de overtreding zelf hadden gemeld en hadden meegewerkt aan het onderzoek. Het destijds geldende boetemaximum van 22.500 euro voor gun-jumping is inmiddels losgelaten.

\section{Airfield Holding}

De zaak Airfield Holding is wellicht het meest leerzame Nederlandse precedent. ${ }^{42}$ Centraal stond de verkoop van Canal+ door Airfield Holding aan Chellomedia. In de 'Framework Agreement' hadden partijen afspraken gemaakt over het beheer van Canal+ tot de aandelenoverdracht. Airfield Holding zou de activiteiten van Canal+ beheren conform een bedrijfsplan, terwijl Chellomedia vetorechten kreeg over veranderingen van dit bedrijfsplan, het aangaan van belangrijke overeenkomsten, uitgaven boven 50.000 euro en het ontslaan van senior managers. De NMa oordeelt dat Chellomedia door deze afspraken reeds zeggenschap had verkregen vóór goedkeuring. Ook de Rechtbank Rotterdam concludeert dat Chellomedia de mogelijkheid had gekregen 'beslissende invloed uit te oefenen op het strategische commerciële gedrag van Canal+'. ${ }^{43}$ Daarbij speelde mee dat een uitgave van 50.000 euro voor een mediabedrijf een relatief laag bedrag is. ${ }^{44}$ Partijen betoogden nog dat geen sprake was van een duurzame wijziging van zeggenschap, omdat de afspraken enkel zagen op de periode tussen koop en aandelenoverdracht. Dat wordt (terecht) verworpen, omdat de Framework Agreement een 'blijvende verandering in de zeggenschap over de onderne-

41. Persbericht van de NMa van 8 april 2008 in zaak 6170 (HAL Investments).

42. Besluit NMa van 19 juli 2006, zaak 5461 (Airfield Holding).

43. Rb. Rotterdam 4 maart 2008, ECLI:NL:RBROT:2008:BC9420, AM 2008/8 m.nt. J.W. Fanoy en M\&M 2008/3 m.nt. M.W.J. Jongmans (Airfield Holding).

44. Fanoy meent dat relevant is hoe waarschijnlijk het is 'dat de vetorechten in de betreffende periode worden uitgeoefend', omdat 'de mogelijkheid om invloed uit te oefenen [reëel] moet [...] zijn wil sprake zijn van verkrijging van zeggenschap.' Dat klopt volgens mij niet. Relevant is of de mogelijkheid om beslissende invloed uit te oefenen 'daadwerkelijk kan worden benut' (Gerecht 23 februari 2006, zaak T-282/02, Cementbouw/Commissie, ECLI:EU:T:2006:64, r.o. 58). Een onderneming zal zich niet kunnen verdedigen tegen een vermeende overtreding van art. $34 \mathrm{Mw}$ met de stelling dat de vetorechten in de praktijk nooit zijn gebruikt en/of dat het niet waarschijnlijk was dat de vetorechten zouden worden gebruikt. 
ming' betekende, welke ook na het moment van goedkeuring en de aandelenoverdracht voortduurde. ${ }^{45}$

De rechtbank verwerpt ook de stelling dat de vetorechten een nevenrestrictie bij de concentratie vormden. Dat is wat mij betreft terecht, alleen al omdat deze doctrine niet relevant is voor een beoordeling van een mogelijke overtreding van artikel $34 \mathrm{Mw}$. De doctrine van nevenrestricties bij concentraties bepaalt dat restricties die rechtstreeks verband houden met en noodzakelijk zijn voor de totstandbrenging van een concentratie, automatisch vallen onder de beschikking waarbij de concentratie wordt goedgekeurd. ${ }^{46}$ Als een restrictie niet noodzakelijk is voor de totstandbrenging van een concentratie (bijvoorbeeld een non-compete bepaling van een te lange duur), dan betekent dit enkel dat de restrictie getoetst moet worden aan artikel 6 lid $1 \mathrm{Mw} .{ }^{47}$ Over de vraag of artikel $34 \mathrm{Mw}$ is overtreden zegt dat echter niets: daarvoor is relevant of de vetorechten een concentratie tot stand brengen. ${ }^{48}$

\section{Amlin}

Door de nationalisering van de Fortis-groep werd de Nederlandse Staat eind 2008 eigenaar van de verzekeraar Fortis Corporate Insurance (FCI). ${ }^{49}$ In juli 2009 droeg de Staat zijn aandelen in FCI over aan de Amlingroep, een Britse verzekeraar, zonder de transactie te melden. De NMa werd bekend met de transactie naar aanleiding van berichtgeving in de media en legde een boete op aan zowel de Staat als twee vennootschappen in de Amlin-groep. Het argument dat de in artikel 31 lid 2 Mw geldende premiedrempel voor verzekeraars onduidelijk was vanwege de term 'Nederlandse ingezetenen' werd afgewezen. Volgens de NMa is Amlin een professionele marktpartij die een grote eigen verantwoordelijkheid heeft om op de hoogte te zijn van de geldende regels. Daarbij hoort ook dat men zich goed laat informeren, bijvoorbeeld tijdens een prenotificatiegesprek met de $\mathrm{NMa} .{ }^{50}$ De rechter verwerpt ook de argumenten van de Staat, die onder meer betoogde dat hij geen onderneming was. ${ }^{51}$ De Staat stelt geen beroep in tegen

45. Fanoy meent dat dit 'anders [zou] zijn indien de NMa geen goedkeuring had verleend voor de transactie en daarmee de transactie ook van de baan was geweest. De instemmingsrechten hadden dan een tijdelijk karakter gehad zonder een opvolgende aandelenoverdracht.' Dat lijkt mij niet juist, omdat dit het paradoxale gevolg zou hebben dat het al dan niet bestaan van een inbreuk op art. $34 \mathrm{Mw}$ afhankelijk wordt gesteld van de eventuele goedkeuring door de NMa.

46. Art. $10 \mathrm{Mw}$ en art. 6 lid $1 \mathrm{sub} b$ Concentratieverordening.

47. Zie over de scheidslijn tussen het concentratietoezicht en de in art. 101 en 102 VWEU neergelegde mededingingsregels: Conclusie A-G Kokott 27 april 2017, zaak C-248/16, Austria Asphalt GmbH \& Co OG/Bundeskartellanwalt, ECLI:EU:C:2017:322, rnr. 35.

48. In de zin van art. 3 Concentratieverordening c.q. art. 26 en $27 \mathrm{Mw}$.

49. Besluit NMa 3 mei 2010, zaak 6843/68 (Amlin).

50. Besluit NMa 3 mei 2010, zaak 6843/68 (Amlin), par. 29.

51. Besluit NMa 3 mei 2010, zaak 6843/68 (Amlin), par. 31 en 38-43. het boetebesluit, Amlin wel. Het besluit blijft in stand, maar de rechtbank verlaagt de boete van Amlin wel. ${ }^{52}$

\section{Alcotra}

In het Alcotra-besluit werd zowel koper als verkoper beboet voor het niet melden van een concentratie. ${ }^{53} \mathrm{De}$ koper probeerde nog onder een boete uit te komen omdat de overtreding niet verwijtbaar zou zijn vanwege de 'gecompliceerdheid van de transactie met betrekking tot het (Nederlands) mededingingsrecht' (de concentratie had namelijk geen effect op de Nederlandse markt). Dat lukte niet. Ook voerde de koper tevergeefs aan dat de NMa rekening moest houden met zijn 'onervarenheid met internationale M\&A-transacties'. De NMa verminderde de boetes wel met twintig procent, onder meer omdat partijen uit eigen beweging een 'standstillovereenkomst' hadden gesloten waarmee de uitoefening van zeggenschap door de koper werd opgeschort, totdat alsnog goedkeuring was verkregen. ${ }^{54}$

\section{Saipol}

In 2009 droeg Bunge 33,34 procent van de aandelen in Saipol over aan de Sofiprotéol-groep. ${ }^{55}$ Hierdoor wijzigde de zeggenschap over Saipol van gezamenlijk (Bunge en Sofiprotéol) naar uitsluitend (Sofiprotéol). Enige tijd later berichtte Sofiprotéol de NMa dat zij een concentratie tot stand had gebracht, die gemeld had moeten worden. Bunge voert dan aan dat geen concentratie tot stand is gebracht, aangezien Sofiprotéol reeds vóór de aandelenoverdracht uitsluitende zeggenschap had over Soprol. Dat zou blijken uit de deadlock-bepaling in de sinds 2003 tussen Bunge en Sofiprotéol geldende aandeelhoudersovereenkomst. Hiermee zou Sofiprotéol haar wil hebben kunnen doordrukken bij strategische beslissingen. De NMa ziet dit anders, onder meer omdat het doordrukken van een strategische beslissing volgens de aandeelhoudersovereenkomst contractbreuk zou zijn waardoor Sofiprotéol schadeplichtig zou worden. ${ }^{56}$ De uitkomst is een boete voor beide partijen.

\section{NPM Capital}

Saillant aan de NPM-zaak is dat de partij die uitsluitende zeggenschap had verkregen ten tijde van het boetebesluit de concentratie nog steeds niet had gemeld. ${ }^{57}$ Naast een boete legde de NMa daarom een last onder dwangsom op met de verplichting binnen vier weken een vol-

52. Rb. Rotterdam 23 mei 2013, ECLI:NL:RBROT:2013:CA1229 (Amlin) r.o. 8. De rechtbank had de NMa eerder in een tussenvonnis via een zogenoemde 'bestuurlijke lus' de kans gegeven haar boeteberekening nader te onderbouwen (Rb. Rotterdam 28 juni 2012, ECLI:NL:RBROT: 2012:BW9829 (Amlin)). De NMa was daar volgens de rechtbank niet in geslaagd. Zie over het gebruik van de bestuurlijke lus bij bestuurlijke boeten: ABRvS 5 juli 2017, ECLI:NL:RVS:2017:1818, AB 2017, 386 en Conclusie staatsraad A-G Keus 12 april 2017, ECLI:NL:RVS:2017:1034.

53. Besluit NMa 18 februari 2010, zaak 6759/75 (Alcotra)

54. Besluit NMa 18 februari 2010, zaak 6759/75 (Alcotra), par. 5. In het verleden heeft de NMa het sluiten van een standstillovereenkomst soms wel (Besluit NMa 13 oktober 2000, zaak 1316 (Heywood Scheuten)) en soms niet (Besluit NMa 13 december 2001, zaak 2400 (NN-ASR ArboDuo)) als boeteverlagende omstandigheid beschouwd.

55. Besluit NMa 17 december 2010, zaak 6905/72 (Saipol).

56. Besluit NMa 17 december 2010, zaak 6905/72 (Saipol), par. 19-25.

57. Besluit NMa 11 februari 2010, zaak 6705/64 (NPM Capital). 
ledige melding te doen van de tot stand gebrachte concentratie. ${ }^{58}$ Als NPM Capital in gebreke zou blijven, zou zij een dwangsom van 10.000 euro voor iedere dag verbeuren met een maximum van 400.000 euro. NPM Capital ging overstag en meldde de concentratie alsnog, waarna deze ook werd goedgekeurd.

In deze zaak had de verkoper, Driesprong, ook een boete gekregen. Driesprong had daartegen niet tijdig bezwaar gemaakt, maar deed vervolgens toch een verzoek bij $\mathrm{NMa}$ om de reeds betaalde boete terug te storten. ${ }^{59}$ Aanleiding voor dat verzoek was de uitspraak van het $\mathrm{CBb}$ in de Pacton-zaak, waarin was geoordeeld dat het in artikel $34 \mathrm{Mw}$ neergelegde verbod zich niet richt tot de verkoper. ${ }^{60}$ De NMa had Driesprong dus niet mogen beboeten. Desondanks wordt het herzieningsverzoek van Driesprong afgewezen. Dat gebeurt met een verwijzing naar het beginsel van formele rechtskracht, waardoor uitgegaan moest worden van de rechtmatigheid van het boetebesluit. ${ }^{61}$

\section{Pacton}

De Pacton-zaak is van belang omdat de verkopende partij na een vergeefs bezwaar bij de NMa en een verloren beroep bij de Rechtbank Rotterdam, de principiële vraag aan het $\mathrm{CBb}$ voorlegde of de NMa de bevoegdheid heeft ook de verkopende partij te beboeten. Het $\mathrm{CBb}$ oordeelt dat de term 'tot stand brengen van een concentratie' in artikel $34 \mathrm{Mw}$ gelezen moet worden in het licht van het begrip 'concentratie' in artikel $27 \mathrm{Mw}$. Artikel $27 \mathrm{Mw}$ definieert dat begrip als het 'verkrijgen van zeggenschap over een onderneming'. ${ }^{62}$ Die term biedt, gelezen in het licht van de wetsgeschiedenis, geen aanknopingspunt om ook de verkoper aan te merken als een partij die de concentratie tot stand brengt, nu deze partij enkel zeggenschap verliest. Het $\mathrm{CBb}$ oordeelt dan ook dat de NMa niet bevoegd is de verkoper te beboeten voor een overtreding van artikel $34 \mathrm{Mw} .{ }^{63}$ Daarmee sluit het Nederlandse concentratietoezicht aan bij het Europese regime.

\section{Motorhuis}

Motorhuis verkreeg op 1 januari 2012 zeggenschap over enkele vennootschappen van de Bulters-groep, zonder dit te melden bij de NMa. Vervolgens legt de NMa boetes op aan Motorhuis en haar twee moedervennootschappen. ${ }^{64}$ De NMa verwerpt het verweer dat de moe-

58. Besluit NMa 11 februari 2010, zaak 6705/64 (NPM Capital), par. 60.

59. Besluit NMa 9 mei 2012, zaak 7385/6 (Driesprong), par. 4.

60. CBb 24 februari 2012, ECLI:NL:CBB:2012:BV6874, NJB 2012/794 (Pacton).

61. Op Europees niveau wordt dit beginsel ook erkend (HvJ EG 14 september 1999, zaak C-310/97, AssiDomän Kraft Products, ECLI:EU:C: 1999:407, r.o. 54. De Commissie zal onder omstandigheden een wijzigingsbeschikking adopteren waarmee het boetebedrag wordt verlaagd (Beschikking van de Commissie van 16 juni 2017 in zaak COMP/ 38.238 (Ruwe Tabak - Spanje)).

62. CBb 24 februari 2012, ECLI:NL:CBB:2012:BV6874, NJB 2012/794 (PaCton), r.o. 5.2

63. CBb 24 februari 2012, ECLI:NL:CBB:2012:BV6874, NJB 2012/794 (PaCton), r.o. 5.6 en 5.7. Daarover werd eerst ook wel anders gedacht. Zie E.E.J. Hessels, 'Melden van concentraties - op wie rust de meldplicht?', V\&O 2010, nr. 4, p. 81-84.

64. Besluit NMa 28 maart 2013, zaak 7491 (Motorhuis), par. 32. dervennootschappen niet beboet kunnen worden. Alle rechtspersonen aan de kopende zijde zijn als onderdeel van dezelfde economische eenheid bij de concentratie betrokken en gelden derhalve als normadressaat. De NMa verlaagt de basisboete met 20 procent, omdat partijen een standstillovereenkomst hebben gesloten en volledige medewerking hebben verleend. Dat Motorhuis zich heeft laten bijstaan door een juridisch adviseur is geen boetematigende omstandigheid. ${ }^{65}$ Motorhuis profiteert wel van de evenredigheidstoets die de NMa hanteert, waarbij de NMa de waarde van de gemelde transactie en de voorgenomen boete vergelijkt. Dat leidt tot een boete van 500.000 euro. $^{66}$

\section{Nederlandse Zorgautoriteit}

In 2017 heeft de Nederlandse Zorgautoriteit voor het eerst een boete opgelegd vanwege een overtreding van de meldingsplicht in de Wet marktordening gezondheidszorg. ${ }^{67}$ Een partij die zichzelf aangaf, kreeg een boete van 70.000 euro. Het argument dat de boete verlaagd moest worden omdat er 'er waarschijnlijk meer transacties zijn die ten onrechte niet bij de NZa worden gemeld' overtuigde de NZa niet. ${ }^{68}$ Hetzelfde gold voor het argument dat de gemachtigde van 'een bevriende advocaat' had begrepen dat de NZa in eerdere en vergelijkbare zaken geen boete had opgelegd. Ondernemingen in de zorgsector zijn dus gewaarschuwd: ook de NZa legt boetes op wanneer haar toezichtfunctie wordt ondermijnd. ${ }^{69}$

\section{Koelvrieshuizen}

De Koelvrieshuizen-zaak is een voorbeeld van een overtreding van artikel 6 lid $1 \mathrm{Mw}$ in een transactiepraktijk. Kloosbeheer onderhandelde met concurrent H\&S Coldstores over een structurele samenwerking. Tijdens de onderhandelingen, die meer dan drie jaar duurden (maar uiteindelijk afketsten), werden prijs-, markt- en klantverdelingsafspraken gemaakt en klantinformatie uitgewisseld. Volgens de ACM hadden de ondernemingen in minstens vijf gevallen offertes afgestemd. Kloosbeheer schikte met de ACM en kreeg een boete van circa 1,2 miljoen euro. ${ }^{70} \mathrm{H} \& \mathrm{~S}$ Coldstores ging echter in beroep en kreeg gelijk van de Rechtbank Rotterdam. De

65. Dit argument werkt ook niet ook op Europees niveau. Zie HvJ EU 18 juni 2013, zaak C-681/11, Schenker, ECLI:EU:C:2013:404, r.o. 41.

66. Besluit NMa 28 maart 2013, zaak 7491 (Motorhuis), par. 56. De evenredigheid van bestuursrechtelijke boetes staat de laatste tijd in de belangstelling. Zie uitgebreid M.L. van Emmerik en C.M. Saris, 'Evenredige bestuurlijke boetes', in: Boetes en andere bestraffende sancties, een nieuw perspectief?, Preadviezen VAR, VAR-reeks 152, nr. 152, Den Haag: Boom Juridische uitgevers 2014.

67. Besluit NZa 30 november 2017, zaak 241773, par. 160. Het betrof in deze zaak een overtreding van art. 49a Wmg. Andere 'sector-meldplichten' bij wijziging van zeggenschap zijn te vinden in art. $86 \mathrm{f}$ lid 1 Elektriciteitswet en art. 66e lid 1 Gaswet.

68. Besluit NZa 30 november 2017, zaak 241773, par. 157

69. Besluit NZa 30 november 2017, zaak 241773, par. 187. De NZa zag onvoldoende belang om de naam van de beboete partij openbaar te maken, omdat 'stakeholders [...] op de hoogte [zijn] van de omstandigheid dat er pas ná het realiseren van de concentratie een aanvraag tot goedkeuring is ingediend bij de NZa'.

70. Besluit ACM 22 december 2015, zaaknummer 13.0698.31 (Kloosbeheer). 
rechtbank oordeelde dat de ACM fouten had gemaakt in de geografische afbakening van de markt en onvoldoende had bewezen dat de verschillende handelingen van partijen wegens hun gemeenschappelijk doel deel uitmaken van een totaalplan om de mededinging te beperken. De rechtbank oordeelde dat de gedragingen 'tot op grote hoogte ook zouden kunnen hebben plaatsgevonden met het oog op de beoogde samenwerking en/of overname. ${ }^{71}$ Gelet op de fundamentele aard van deze fouten biedt de rechtbank de ACM geen ruimte voor herstel via een bestuurlijke lus maar herroept zij het boetebesluit.

Deze uitkomst is op het eerste gezicht verrassend. Er zijn weinig legitieme redenen te bedenken waarom partijen in de aanloop naar een structurele samenwerking hun bestaande commerciële marktgedrag, zoals hun prijsgedrag, zouden moeten afstemmen. Sommige in de uitspraak geciteerde e-mails lijken niets te maken te hebben met een normale M\&A-transactie ('(...) Ik had al een aantal maanden eerder aangegeven dat wij een deel van deze lading bij hem [ [persoon B] ] zouden onderbrengen aangezien zij structureel op $60 \%$ zitten en elke offerte hoger aanbieden waarbij in ieder geval onze klanten behouden'). ${ }^{72}$ Wellicht heeft de ACM het zichzelf te moeilijk gemaakt door een totaalplan te willen bewijzen. ${ }^{73}$ Een moeilijke vraag is welke informatie concurrenten wél mogen delen. In mijn optiek verloopt die analyse via twee stappen. Eerst moet vastgesteld worden of de gedeelde informatie de strategische onzekerheid op de markt kan verminderen. ${ }^{74}$ Dat zal eerder het geval zijn bij gedetailleerde klant- en prijsinformatie dan bij geaggregeerde en geanonimiseerde kosteninformatie. Vervolgens moet getoetst worden of het delen van informatie 'objectief noodzakelijk' is voor het totstandbrengen van de voorgenomen concentratie, bijvoorbeeld vanwege het correct waarderen van de target. ${ }^{75} \mathrm{Bij}$ het delen van zeer gevoelige informatie zal nagedacht moeten worden over het organiseren van een 'clean team' ${ }^{76}$ Volgens Naughton mogen partijen meer informatie delen vóór het moment van signing dan daarna, omdat de waardering van de doelvennootschap na signing gewoonlijk afgerond is. ${ }^{77}$ Blumenthal stelt ten slotte dat de mate waarin informatie-uitwisseling geoorloofd is

71. Rb. Rotterdam 12 april 2018, ECLI:NL:RBROT:2018:2787 (H\&S Coldstores).

72. Rb. Rotterdam 12 april 2018, ECLI:NL:RBROT:2018:2787 (H\&S Coldstores), r.o. 8.6

73. Vgl. CBb 3 juli 2017, ECLI:NL:CBB:2017:204 (Executieveilingen).

74. Richtsnoeren inzake de toepasselijkheid van artikel 101 van het Verdrag betreffende de werking van de Europese Unie op horizontale samenwerkingsovereenkomsten (2011/C 11/01), par. 55-110.

75. Vgl. Mededeling van de Commissie betreffende beperkingen die rechtstreeks verband houden met en noodzakelijk zijn voor de totstandbrenging van concentraties (2005/C 56/03)

76. Zie hierna de bespreking van Besluit Franse mededingingsautoriteit 8 november 2016, zaak 16-D-24 (Altice).

77. M.C. Naughton, 'Gun-Jumping and Pre-Merger Information Exchange: Counseling the Harder Questions', ANTITRUST 2006, vol. 20, nr. 3, p. 10. ook afhangt van de vraag of de voorgenomen concentratie inhoudelijk gezien mogelijk tot bezwaren zal leiden. ${ }^{78}$

\section{Europese zaken}

De periode waarin de Commissie geen ${ }^{79}$ of relatief lage ${ }^{80}$ boetes oplegde aan ondernemingen voor gun-jumping is voorbij. $\mathrm{Na}$ een aantal onderzoeken waarin geen inbreuken werden vastgesteld, ${ }^{81}$ werd het Belgische elektriciteitsbedrijf Electrabel in 2009 beboet met twintig miljoen euro. Eenzelfde boete werd in 2014 opgelegd aan de Noorse viskweker Marine Harvest. Die boetes vallen echter in het niet bij de recente boete voor telecombedrijf Altice van 124,5 miljoen euro. Zijn deze zaken laaghangend fruit voor de Commissie of is er iets anders aan de hand? Volgens mij het laatste. De Commissie benadrukt steeds weer het ondermijnende effect van deze overtredingen op het fusiecontroleregime: zonder meldingen werkt het systeem niet. Dat verklaart mogelijk ook waarom andere procedurele overtredingen de laatste jaren hard worden afgestraft. ${ }^{82}$

Inmiddels zijn ook door de mededingingsautoriteiten van de lidstaten tientallen boetes opgelegd wegens overtredingen van nationale meldings- en standstillverplichtingen. ${ }^{83}$ Meestal zijn dat relatief simpele zaken, waarbij partijen uit onoplettendheid vergeten hun concentratie te melden. Het gaat daarbij vaak om situaties waar activa worden overgedragen. ${ }^{84} \mathrm{Er}$ zijn echter ook gevallen bekend van partijen die opzettelijk het concentratiecon-

78. Volgens Blumenthal moet onder Section 1 van de Sherman Act het delen van informatie tijdens een M\&A-transactie getoetst worden onder een 'ancillary-restraints analysis', waarbij doorslaggevend is of het delen van informatie redelijkerwijs noodzakelijk is 'to protect the core transaction'. Zie Speech W. Blumenthal, 'The Rhetoric of Gun-Jumping', 10 november 2005, p. 8.

79. Persbericht Europese Commissie 1 december 1997, 'Commission warns Bertelsmann and Kirch against infringement of European merger control', IP/97/1062; Besluit Europese Commissie 26 juni 2002, zaak M.2650 (Haniel/Cementbouw/JV(CVK)); Besluit Europese Commissie 5 oktober 1992, zaak IV/M.157 (Air France/Sabena), par. 21; Besluit Europese Commissie 17 juni 2010, zaak M.5365 (IPO/EnBW/Praha/ PT), par. 7 en 36; Besluit Europese Commissie 21 september 2007, zaak M.4730 (Yara/Kemira GrowHow).

80. Besluit Europese Commissie 18 februari 1998, zaak IV/M 920 (Samsung/AST); Besluit Europese Commissie 10 februari 1999, zaak IV/M 969 (A/P Møller).

81. Persbericht Europese Commissie 13 december 2007, 'Mergers: Commission has carried out inspections in the S PVC sector, MEMO/07/573 (onaangekondigde inspecties vanwege verdenking van inbreuk op art. 7 lid 1 Concentratieverordening en art. 101 VWEU); Besluit Europese Commissie 19 oktober 2011, zaak M.6106 (Caterpillar/MWM) (onaangekondigde inspecties vanwege verdenking van inbreuk op art. 7 lid 1 en art. 11 Concentratieverordening).

82. Besluit Europese Commissie 18 mei 2017, zaak M.8228 (Facebook).

83. Zie het uitvoerige overzichtsartikel: D. Hull en C. Gordley, 'Gun Jumping in Europe: An overview of EU and National Case Law', Concurrences 2018.

84. Vgl. Besluit Poolse mededingingsautoriteit 19 september 2017 (Fermy Drobiu Woźniak sp. z.o.o.) (niet melden van overdracht activa). De Mededeling Bevoegdheidskwesties van de Commissie hanteert het uitgangspunt dat activa een (deel van een) onderneming kunnen zijn als er marktomzet aan toe te rekenen is. Vooral met outsourcing kan dit moeilijkheden opleveren. Zie J. Lohrberg en M. Huhtamäki, 'Outsourcing Transactions and Merger Control', ECLR 2008, nr. 6. 
troleregime wilden ontduiken. ${ }^{85}$ Dat is uiteraard een boeteverhogende omstandigheid. Het gaat de reikwijdte van dit artikel te buiten om een overzicht te geven van alle Europese zaken. Ik beperk mij tot de handhavingsactiviteiten van de Commissie, de prejudiciële vragen in de $E Y$-zaak en de recente Altice-zaak van de Franse mededingingsautoriteit.

\section{Electrabel}

In 2009 gaf de Commissie in de Electrabel-zaak een sterk signaal dat gun-jumping tot miljoenenboetes kan leiden. ${ }^{86}$ Electrabel had in 2003 haar belang in het Franse elektriciteitsbedrijf Compagnie Nationale du Rhone (CNR) vergroot van 17,68 procent naar 49,95 procent (met 47,92 procent stemrechten), zonder de Commissie op de hoogte te stellen. Toen Electrabel in 2007 informeel de Commissie benaderde met de vraag of zij wellicht al in 2003 de facto zeggenschap had verkregen over CNR, beantwoordde de Commissie deze vraag bevestigend. Electrabel had namelijk met haar minderheidsbelang feitelijk gezien altijd haar wil kunnen doordrukken op de aandeelhoudersvergadering, gelet op de lage historische aanwezigheid van de overige minderheidsaandeelhouders. ${ }^{87}$ Ook speelde mee dat Electrabel sinds 2003 als enige industriële aandeelhouder het beheer voerde over de centrales van CNR. De Commissie legt een boete op van twintig miljoen euro wegens een ongeveer vijfjarige overtreding van de standstillverplichting. ${ }^{88}$ Deze boete blijft in stand bij het Gerecht en het Hof van Justitie. ${ }^{89}$

85. Besluit Duitse mededingingsautoriteit 13 februari 2009 (Druck- und Verlagshaus Frankfurt am Main $\mathrm{GmbH}$ ) (opzettelijk ontduiken concentratiecontrole); Besluit Franse mededingingsautoriteit 20 december 2013, zaak 13-D-22 (Castel Frères/Patriarche). Zie ook Besluit NMa 28 juni 2000, zaak 1774 (Verkerk-Horn).

86. Besluit Europese Commissie 10 juni 2009, zaak M.4998 (Electrabel/ CNR). Zie F. Carloni, 'Electrabel v Commission \& COMP M.7184 Marine Harvest/Morpol: Gun-jumping and Violation of the Merger Standstill Obligation in Europe', JCLAP 2014, vol. 5, nr. 10, p. 693-696; B. Alomar, S. Moonen, G. Navea en P. Redondo, 'Electrabel/CNR: the importance of the standstill obligation in merger proceedings', Competition Policy Newsletter 2009, nr. 3, p. 58-60.

87. Geconsolideerde mededeling van de Commissie over bevoegdheidskwesties op grond van Verordening (EG) nr. 139/2004 betreffende de controle op concentraties van ondernemingen, PbEU 2008, C 95 par. 59 (hierna: Geconsolideerde Mededeling Bevoegdheidskwesties). Zie ook Besluit Europese Commissie 22 december 1997, zaak IV/M. 1058 (UniChem/Alliance Santé) (de facto zeggenschap met 36 procent minderheidsaandeel); Besluit Europese Commissie 30 augustus 2008, zaak M.5250 (Porsche/Volkswagen) (concentratie door verwerving aandelen van 30,9 procent naar 35,52 procent); Besluit Europese Commissie 24 juni 2008, zaak M.5121 (News Corp/Premiere) (vergroting aandelenbelang van 24,2 procent naar 29,9 procent in samenhang met lagere verwachte opkomst andere aandeelhouders).

88. In Electrabel stelt de Commissie enkel een inbreuk vast op art. 7 lid 1 Concentratieverordening en niet op art. 4 lid 1 Concentratieverordening. Dat kan te maken hebben met de kortere verjaringstermijn voor inbreuken op art. 4 lid 1 Concentratieverordening. Zie P. Honoré en G. Vatin, 'The French Competition Authority's Altice Decision: Record Fine for the First 'Genuine' Gun Jumping Case in Europe', JCLAP 2017, vol. 8, nr. 5, p. 314-320

89. Gerecht 12 december 2012, zaak T-332/09, Electrabel, ECLI:EU:T: 2012:672; HvJ EU 3 juli 2014, zaak C-84/13, Electrabel, ECLI:EU:C: 2014:2040.

\section{Marine Harvest}

De Electrabel-zaak laat zien dat het vaststellen van een wijziging van zeggenschap, zeker als het de facto zeggenschap betreft, een complexe exercitie kan zijn. Ook bij een openbaar bod bestaan de nodige mededingingsrechtelijke valkuilen. Het ligt dan voor de hand in een vroeg stadium een mededingingsspecialist in te schakelen. Marine Harvest deed dat niet, maar vroeg op het laatste moment juridisch advies op basis van onvolledige informatie. ${ }^{90}$ De uitkomst (een boete van twintig miljoen euro) onderstreept het risico van een complexe transactie gecombineerd met weinig aandacht voor de mededingingsrechtelijke aspecten.

De feiten zijn als volgt. Marine Harvest, een viskweker, had in 2012 het plan opgevat om haar concurrent Morpol over te nemen. Morpol stond genoteerd aan de beurs van Oslo, waar ongeveer 48,5 procent van de aandelen in handen waren van haar CEO, de heer Malek. Marine Harvest wilde eerst het aandelenpakket van deze CEO overnemen en daarna een openbaar bod doen op de resterende aandelen. ${ }^{91}$ Zo geschiedde. Marine Harvest verkreeg op 18 december 2012 de aandelen van de CEO. Op 21 december 2012 stuurde Marine Harvest een informeel bericht aan de Commissie met de strekking dat zij de stemrechten van de Morpol-aandelen niet zou uitoefenen, totdat de concentratie gemeld was en goedgekeurd. Vervolgens deed Marine Harvest op 15 januari 2013 een openbaar bod op de rest van de aandelen. Op 9 augustus 2013 meldde Marine Harvest de concentratie formeel aan bij de Commissie, waarna de concentratie op 30 september 2013 onder voorwaarden werd goedgekeurd. In november 2013 haalde Marine Harvest Morpol van de beurs.

Marine Harvest meende dat haar handelswijze gedekt was door artikel 7 lid 2 Concentratieverordening. Deze vrijstelling van de standstillverplichting is van toepassing op de verwerving van aandelenpakketten van meerdere verkopers (zogenoemde 'creeping bids' of 'sluipende biedingen'), bijvoorbeeld via een openbaar bod. ${ }^{92}$ Er zijn nog twee aanvullende voorwaarden voor toepassing van artikel 7 lid 2: (1) de concentratie wordt onverwijld gemeld bij de Commissie ${ }^{93}$ en (2) de verkrijger mag de aan de effecten verbonden stemrechten niet uitoefenen totdat de Commissie de concentratie heeft goedgekeurd of ontheffing is verleend. ${ }^{94}$

90. Gerecht 26 oktober 2017, zaak T-704/14, Marine Harvest, ECLI:EU:T: 2017:753, r.o. 268, waarin een e-mail aan de mededingingsadvocaat van Marine Harvest wordt geciteerd die gestuurd is op de dag dat de koopovereenkomst werd getekend ('The latest draft is attached for your review and comments from a competition law point of view. Not unusually, no one has focused much on this particular aspect up until now. $\left.(\ldots)^{\prime}\right)$.

91. Vgl. Besluit Europese Commissie 21 september 2007, zaak M.4730 (Yara/Kemira GrowHow) waarin ook sprake was van de verwerving van een 'build-up stake' gevolgd door een openbaar bod.

92. Vgl. art. $39 \mathrm{Mw}$.

93. De koper loopt door gebruik van deze vrijstelling wel een commercieel risico omdat hij een deel van zijn aandelen zal moeten verkopen als de Commissie de concentratie verbiedt (vgl. Besluit Europese Commissie 30 januari 2002, zaak M.2283 (Schneider/Legrand)).

94. Art. 7 lid 3 Concentratieverordening. 
Hoewel Marine Harvest haar stemrechten inderdaad niet had uitgeoefend tot de goedkeuring, was dat volgens de Commissie niet relevant. Marine Harvest had namelijk reeds vóór het openbaar bod uitsluitende zeggenschap verkregen over Morpol door de aankoop van het aandelenpakket van de CEO. Het latere openbare bod was dus irrelevant voor de wijziging van zeggenschap. Los daarvan was niet voldaan aan het vereiste van 'meerdere verkopers', aangezien Marine Harvest 'de zeggenschap over Morpol in de onderhavige zaak van één enkele verkoper heeft verworven via één enkele transactie met effecten'. ${ }^{95}$

In haar beschikking legt de Commissie een boete op van twintig miljoen euro voor overtreding van zowel artikel 4 lid 1 als artikel 7 lid 1 Concentratieverordening. Daarbij hield de Commissie rekening met het feit dat Marine Harvest eerder een nationale standstillverplichting had geschonden. ${ }^{96}$ Het Gerecht laat beide boetes in stand. Nieuw is dat het Gerecht drie casusposities onderscheidt inzake de ernst van de inbreuk: ${ }^{97}$

1. De vroegtijdig geimplementeerde concentratie veroorzaakte geen mededingingsproblemen. In dat geval is de inbreuk (naar zijn aard) ernstig.

2. De vroegtijdig geimplementeerde concentratie veroorzaakte wél mededingingsproblemen. Dat maakt de inbreuk ernstiger dan in scenario (1).

3. Een 'tussensituatie' waarin ernstige twijfels bestaan over de verenigbaarheid met de interne markt van de vroegtijdig geïmplementeerde concentratie, maar 'niet kan worden bepaald of de totstandbrenging ervan in de aanvankelijk voorziene en niet door de Commissie goedgekeurde vorm schadelijke gevolgen voor de mededinging heeft gehad of niet'. In dat geval is de inbreuk ernstiger dan scenario (1), maar minder erg dan scenario (2), tenzij het in een bepaald geval 'kan worden uitgesloten' dat de concentratie schadelijke gevolgen voor de mededinging had.

Het is de vraag of een onderneming praktisch gezien kan bewijzen dat enig mededingingsbeperkend effect afwezig is. Marine Harvest lukte dat in ieder geval niet. De Commissie wees namelijk onder meer op de mogelijkheid dat Marine Harvest - vanwege de aandelenoverdracht - een groot deel van de winst van Morpol had ingelijfd. Daardoor zouden mogelijk de prikkels zijn verminderd om concurrentiedruk te blijven uitoefenen op Morpol. Het Gerecht vindt dat ook en oordeelt dat de Marine Harvest-casus een 'tussensituatie' is. ${ }^{98} \mathrm{Ma}-$ rine Harvest heeft hoger beroep ingesteld tegen het arrest van het Gerecht. ${ }^{99}$

95. Gerecht 26 oktober 2017, zaak T-704/14, Marine Harvest, ECLI:EU:T: 2017:753, r.o. 75

96. Besluit Europese Commissie 23 juli 2014, zaak M.7184 (Marine Harvest), par. 159-163.

97. Gerecht 26 oktober 2017, zaak T-704/14, Marine Harvest, ECLI:EU:T: 2017:753, r.o. 494

98. Zaak T-704/14, Marine Harvest, r.o. 517

99. Zaak C-10/18, Marine Harvest.

\section{Canon}

Centraal staat een 'parehousing-constructie'100 die Canon gebruikte om Toshiba Medical Systems Corporation (TMSC) over te nemen (een 100 procent dochtervennootschap van Toshiba). Als eerste stap werd een 'special purpose vehicle' opgericht, die 95 procent van de aandelen in Toshiba Medical Systems verkreeg van Toshiba voor het symbolische bedrag van 800 euro. ${ }^{101}$ Canon betaalde Toshiba daarentegen een bedrag van 5,28 miljard euro. Daarvoor verkreeg Canon een vetorecht over bepaalde gedragingen van TMSC én een aandelenoptie op de resterende 95 procent van de aandelen. ${ }^{102}$ Canon mocht deze aandelenoptie volgens de transactiedocumentatie pas uitoefenen na mededingingsrechtelijke goedkeuring. Na voltooiing van de hiervoor beschreven aandelenoverdrachten werd de transactie gemeld bij de Commissie en goedgekeurd. Vervolgens gebruikt Canon haar aandelenoptie en verkrijgt zij uitsluitende zeggenschap over TMSC.

Op 6 juli 2017 maakte de Commissie bekend dat zij een onderzoek was gestart naar deze transactiestructuur. ${ }^{103}$ Het voorlopig oordeel van de Commissie was dat de transactie 'essentially allowed [Canon] to acquire Toshiba Medical Systems prior to obtaining the relevant merger approvals'. Dat is in lijn met de Geconsolideerde Mededeling Bevoegdheidskwesties, waarin de Commissie de situatie beschrijft waarin een onderneming 'geparkeerd' wordt bij een tussentijdse koper op basis van een overeenkomst betreffende de toekomstige verkoop van het bedrijf aan een uiteindelijke verkrijger. ${ }^{104}$ In dat geval zal de Commissie de transactie waarmee de tussentijdse koper zeggenschap verkrijgt, beschouwen als de eerste stap van één enkele concentratie die de verkrijging van zeggenschap door de uiteindelijke koper omvat. Dat betekent dat goedkeuring moet zijn verkregen vóór het uitvoeren van de eerste stap. In de Canonzaak speelde wellicht ook mee dat Canon reeds vóór goedkeuring bepaalde vetorechten had verkregen over TMSC. ${ }^{105}$ Het is afwachten of het onderzoek van de

100. De term 'warehousing' of 'parkeerconstructie' wordt soms ook gebruikt in verband met de uitzondering voor tijdelijke deelnemingen door financiële instellingen in art. 3 lid 5 sub a Concentratieverordening. Zie M.A. de Jong, 'Lagardère-zaak: comeback van de parkeerconstructie?', M\&M 2013/1, p. 13-18. De Canon-zaak gaat niet over deze situatie.

101. De aandeelhouders van de SPC waren drie natuurlijke personen met elk een deelneming van 33,3 procent. Het is niet bekend of deze personen met Canon geassocieerd waren.

102. Canon kreeg volgens de statuten van TMSC vetorechten over: "1. Determining matters concerning the issuance of shares for subscription and share options for subscription; 2. Giving the approval under Article 179-3(1) of the Companies Act; 3. Aquiring treasury shares; or 4. Undergoing a merger, company split, share exchange, share transfer or other organizational restructuring' [cursivering toegevoegd]. Zie Besluit Europese Commissie 19 september 2016, zaak M.8006 (Canon/Toshiba Medical Systems Corporation), par. 7, voetnoot 5 .

103. Persbericht Europese Commissie 6 juli 2017, 'Mergers: Commission alleges Merck and Sigma-Aldrich, General Electric, and Canon breached EU merger procedural rules'. Ook de Chinese en Japanse autoriteiten hebben deze transactie onderzocht en zijn tot de conclusie gekomen dat sprake was van gun jumping.

104. Geconsolideerde Mededeling Bevoegdheidskwesties, par. 35.

105. Een situatie waarin een koper de verkoper voor goedkeuring de koopprijs betaalt, zal op zichzelf niet kwalificeren als gun-jumping (Besluit Europese Commissie 22 mei 2007, zaak M.4404 (Universal/BMG)). 
Commissie inderdaad resulteert in een boete ${ }^{106}$ en wat dat zal betekenen voor de praktijk waar parehousing soms wordt gebruikt om een gelijk speelveld te creëren tussen strategische en financiële kopers. ${ }^{107}$

Altice

Op 17 mei 2017 maakte de Commissie bekend dat zij vermoedde dat telecombedrijf Altice de gun-jumpingregels had overtreden bij de overname van PT Portugal. Het persbericht stelt dat: ${ }^{108}$

'[A]ltice door de koopovereenkomst tussen de twee ondernemingen in een positie is gekomen waarin het beslissende invloed kon uitoefenen op PT Portugal voordat de transactie was aangemeld of goedgekeurd, en dat Altice in bepaalde gevallen daadwerkelijk beslissende invloed op PT Portugal heeft uitgeoefend.'

De nadruk op de koopovereenkomst suggereert dat hier sprake was van uitgebreide pre-completion convenants. Dat is een onderwerp waar tot dusver weinig Europese handvatten voor bestaan en waar nadere toelichting welkom is. Een dag na publicatie van het persbericht gaf Vestager in een speech iets meer informatie over de aanleiding van het onderzoek ('We were surprised to read in the newspapers that executives from Altice had been visiting PT Portugal.'), de verdenking van een vroegtijdige totstandbrenging van de concentratie ('It appears that Altice had already been acting as if it owned PT Portugal. It seems that it gave instructions on how to handle commercial issues, such as contract negotiations.') én het feit dat de Commissie vermoedt dat spra$\mathrm{ke}$ is van ongeoorloofde informatie-uitwisselingen ('And [Altice] also seems to have been given sensitive information. Information that only PT Portugal's owner should have had - and without any safeguards to stop it misusing that information.' $)^{109}$ Op 24 april 2018 makte de Commissie bekend dat Altice een recordboete opgelegd had gekregen van 124,5 miljoen euro, onder andere vanwege te vergaande pre-completion covenants, het uitwisselen van informatie buiten het raamwerk van een geheimhoudingovereenkomst en de omstandigheid dat Altice aan PT Portugal instructies had gegeven over het voeren van een marketingcampagne. ${ }^{110}$ Het tot dusver niet openbaar gemaakte boetebesluit zal in de toekomst

106. Canon zal wellicht betogen dat een aandelenoptie op zichzelf niet tot zeggenschap leidt, tenzij de optie op grond van juridisch bindende overeenkomsten in de nabije toekomst zal worden uitgeoefend. Zie Geconsolideerde Mededeling Bevoegdheidskwesties, par. 60

107. Een strategische koper zal soms een complexer fusiecontroletraject doorlopen dan een financiële koper (zoals een investeringsfonds), gelet op een eventuele overlap met bestaande marktactiviteiten. Dat kan een nadeel opleveren voor de strategische koper tijdens een competitief biedingsproces.

108. Persbericht Europese Commissie 18 mei 2017, ‘Concentraties: volgens Commissie schendt Altice EU regels door vroegtijdige overname van PT Portugal', IP/17/1368.

109. M. Vestager, 'Competition and the rule of law', 18 mei 2017.

110. Persbericht Europese Commissie 24 april 2018, 'Mergers: Commission fines Altice $€ 125$ million for breaching EU rules and controlling PT Portugal before obtaining merger approval', IP/18/3522. waarschijnlijk belangrijke guidance worden over deze onderwerpen.

EY

Ook de $E Y$-zaak belooft een belangrijk Europees precedent te worden op het gebied van de reikwijdte van de standstillverplichting. Op het moment van schrijven van dit artikel heeft het Hof van Justitie nog geen arrest gewezen, maar de conclusie van advocaat-generaal Wahl is het bespreken waard. ${ }^{111}$

Aanleiding voor deze zaak was de fusie tussen de Deense vestiging van accountantsnetwerk KPMG (KPMG DK) en accountant Ernst \& Young (EY). KPMG DK maakte vóór de fusie via een samenwerkingsovereenkomst deel uit van de internationale KPMG-groep. Nadat KPMG DK en EY op 18 november 2013 overeenstemming hadden bereikt over hun nog uit te voeren fusie, stuurde KPMG DK op dezelfde dag een bericht naar de internationale KPMG-groep met de strekking dat de samenwerkingsovereenkomst per 30 september 2014 werd opgezegd (dus met ingang van bijna een jaar later). De voorgenomen werd vervolgens gemeld bij de Deense autoriteit en op 28 mei 2014 goedgekeurd. Later sloot KPMG DK zich aan bij EY.

De Deense autoriteit oordeelde dat KPMG DK zich schuldig had gemaakt aan gun-jumping door op 18 november 2013 de samenwerkingsovereenkomst op te zeggen per 30 september 2014. Volgens de Deense autoriteit was daarbij relevant dat het beëindigen van deze overeenkomst (1) specifiek betrekking had op de concentratie, (2) onomkeerbaar was en (3) in het tijdvak tussen de opzegging en de goedkeuring van de concentratie potentieel markteffecten veroorzaakte. ${ }^{112}$ Die laatste omstandigheid werd onderbouwd doordat enkele klanten van KPMG DK na bekendmaking van de voorgenomen fusie naar een andere accountant waren overgestapt. In de beroepsprocedure tegen het boetebesluit stelt de Deense rechter prejudiciële vragen aan het Hof van Justitie.

Advocaat-generaal Wahl is kritisch op het boetebesluit van de Deense autoriteit. Hij stelt dat de reikwijdte van de standstillverplichting van artikel 7 lid 1 Concentratieverordening gekoppeld moet worden aan die van het begrip 'concentratie'.113 Van een overtreding van de standstillverplichting kan sprake zijn bij zowel de gedeeltelijke als volledige totstandbrenging van een concentratie. De moeilijkheid bestaat er volgens advocaatgeneraal Wahl in 'de grens te trekken tussen rechtmatige voorbereidende maatregelen en gedeeltelijke totstandbrenging'. ${ }^{114}$ Zuiver interne maatregelen zijn volgen Wahl in ieder geval geen (gedeeltelijke) totstandbrenging van een concentratie. Volgens hem geldt de standstillverplichting ook niet:

111. Conclusie A-G Wahl 18 januari 2018, zaak C-633/16, EY, ECLI:EU:C 2018:23.

112. Conclusie A-G Wahl, EY, par. 25

113. Conclusie A-G Wahl, EY, par. 68

114. Conclusie A-G Wahl, EY, par. 63 
'[V]oor maatregelen die, hoewel zij zijn getroffen in verband met het proces dat tot een concentratie leidt, aan de maatregelen die daadwerkelijk leiden tot verwerving van de mogelijkheid om een beslissende invloed uit te oefenen op de doelonderneming, voorafgaan en ervan kunnen worden gescheiden.'115

Wahl concludeert dat de beëindiging van de samenwerkingsovereenkomst op geen enkele wijze bijdroeg aan een verschuiving van zeggenschap van KPMG DK naar $\mathrm{EY}$, waardoor het ook niet als een voortijdige totstandbrenging van een concentratie kan worden beschouwd. Effecten op de markt of de onomkeerbaarheid van de maatregel zijn volgens Wahl niet relevant. Daarmee neemt Wahl een andere positie in dan de Commissie, die een veel bredere benadering van de standstillverplichting voorstaat. ${ }^{116}$

\section{Altice (Frankrijk)}

In de Franse Altice-zaak staan twee telecomtransacties centraal: de overname door Altice van SFR en OTL. ${ }^{117}$ Het kernverwijt is dat Altice reeds voor goedkeuring zeer intensief betrokken was bij de operationele werkzaamheden van SFR en OTL. Zo moest SFR goedkeuring vragen aan de CEO van Altice voordat deel werd genomen aan een aanbesteding, beëindigde Altice een reclameactie van SFR voor breedbandinternet en werd intensief overlegd over het gezamenlijk opzetten van een nieuw innovatief product (de Box TV Fibre). Dat nieuwe product werd vervolgens vrijwel direct na goedkeuring van de transactie op de markt gebracht. Tijdens het transactieproces met OTL ging Altice ook de fout in: er was een uitgebreid rapportagesysteem opgezet en de directeur général van OTL bleek reeds voor goedkeuring werkzaamheden te verrichten voor Altice. $\mathrm{Na}$ klachten van marktpartijen deed de Franse autoriteit een inval en legde zij een boete op van 80 miljoen euro.

De zaak illustreert het belang van een zorgvuldige analyse van pre-completion covenants, die beogen de waarde van de doelvennootschap te waarborgen tot het moment dat de zeggenschap daadwerkelijk wordt overgedragen. Vaak wordt de verkoper verplicht zijn onderneming ' in the ordinary course of business' voort te zetten of krijgt de beoogde koper vetorechten over bepaalde buitengewone investeringen of afstotingen van de doelvennootschap. Dat mag. In het geval van Altice waren er echter twee problemen: Altice besliste ook over zaken die 'ordinary business' waren én de doelvennootschap vroeg Altice's

115. Conclusie A-G Wahl, EY, par. 78

116. De Commissie beroept zich op Gerecht 6 juli 2010, zaak T-411/07, Aer Lingus Group/Commissie, ECLI:EU:T:2010:281, r.o. 83. Daarin heeft het Gerecht geoordeeld dat 'de verkrijging van een [minderheids]belang dat als zodanig geen zeggenschap verleent in de zin van artikel 3 van [verordening nr. 139/2004], onder de werkingssfeer van artikel 7 van die verordening [kan] vallen'. A-G Wahl meent dat dit niet kan kloppen, omdat de standstillverplichting zo losgekoppeld wordt van het begrip 'concentratie'. Zie ook: F. Depoortere, 'The Air Lingus Judgment When non-implementation is implementation, or not', Kluwer Competition Law Blog 2010.

117. Besluit Franse mededingingsautoriteit 8 november 2016, zaak 16-D-24 (Altice). goedkeuring over onderwerpen terwijl daartoe geen verplichting bestond onder de koopovereenkomst.

Hoewel de feiten in de Altice-zaak wijzen op een ernstige overtreding van de standstillverplichting, gaat de Franse autoriteit naar mijn idee op het punt van 'clean teams' te ver. Een clean team is een gangbare manier van werken in de transactiepraktijk, waarbij zowel koper als verkoper een selecte groep werknemers die niet betrokken zijn bij dagelijkse commerciële werkzaamheden een geheimhoudingsovereenkomst laat tekenen. Vervolgens delen partijen in een virtuele clean room bedrijfsvertrouwelijk informatie die enkel deze clean team-leden mogen bekijken. Als clean team-leden over de informatie willen rapporteren aan anderen, gebeurt dat op een geaggregeerde en anonieme wijze waardoor geen risico bestaat op mededingingsbeperkende effecten. De Franse autoriteit wil hier echter niets van weten: volgens haar mogen enkel externe adviseurs (zoals advocaten, consultants of bankiers) deelnemen aan het clean team-proces. ${ }^{118}$ Dat zou een zeer onwelkome en dure boodschap zijn aan het bedrijfsleven, terwijl er geen aanwijzingen zijn dat de huidige praktijk niet goed werkt.

\section{Afsluiting}

Advocaten zullen het herkennen: veel ondernemingen willen niet op het scherpst van de mededingingsrechtelijke snede opereren, maar kiezen voor een compliancebenadering waarbij zelfs de minste indruk van een overtreding wordt vermeden. Dat is begrijpelijk gezien de gigantische kosten die gepaard gaan met een onderzoek door een autoriteit. Deze 'better safe than sorry'-benadering kan echter voor de bredere marktwerking nadelig uitpakken, wanneer ook procompetitief gedrag veiligheidshalve wordt vermeden.

Is er nu een risico dat de huidige handhavingspraktijk rond gun-jumping mededingingsbevorderend gedrag afschrikt? Wat mij betreft volstaat een genuanceerd antwoord. Aan de ene kant treden de autoriteiten terecht op tegen partijen die opzettelijk of uit onachtzaamheid concentraties in het geheel niet of te laat melden (Motorhuis, Electrabel en Marine Harvest). Het risico op een chilling effect van mededingingsbevorderende activiteiten lijkt mij hier niet zo groot. Hoogstens worden partijen geprikkeld eerder in het proces mededingingsrechtelijk advies in te winnen.

De autoriteiten handhaven echter ook in gevallen waar de overtreding veel minder duidelijk is. Ik denk dan vooral aan de $E Y$-zaak. Ter illustratie: de Commissie stelt in die zaak dat sprake kan zijn van 'gun-jumping' in het geval van maatregelen die:

'(i) bestaan in voorbereidende stappen tijdens een procedure die tot een wijziging van zeggenschap leidt, of

118. Besluit Franse mededingingsautoriteit 8 november 2016, zaak 16-D-24 (Altice), par. 318. 
(ii) de partij die zeggenschap verwerft, in staat stellen invloed te verwerven over de structuur of het marktgedrag van de doelonderneming, of

(iii) anderszins vooruitlopen op de gevolgen van de concentratie of de bestaande mededingingssituatie aanzienlijk beinvloeden.'

Ik kan hier wel onomwonden stellen dat de toets of maatregelen 'anderszins vooruitlopen op de gevolgen van de concentratie of de bestaande mededingingssituatie aanzienlijk beïnloeden' in de praktijk onwerkbaar is. Ondernemingen verdienen een betere en heldere maatstaf. Blumenthal verwijst in dit verband naar Type IIIfouten: 'the imposition on business and government of excessive transaction costs associated with enabling the public to distinguish between permissible and impermissible conduct'. ${ }^{119}$ Hoge boetes gecombineerd met een brede opvatting van het gun-jumping-verbod kunnen het effect hebben dat ondernemingen minder risico's nemen en ook procompetitieve voorbereidingsmaatregelen opschorten.

Het lijkt dus tijd voor een andere retoriek van de autoriteiten. Dat kan door speeches te houden over wat wél mag, maar het zou nog beter zijn als autoriteiten richtsnoeren opstellen. De Franse autoriteit heeft dat aangekondigd, terwijl ze in Brazilië al bestaan. ${ }^{120}$ De Federal Trade Commission publiceerde recent een korte handleiding over het uitwisselen van informatie tijdens M\&A-transacties. ${ }^{121}$ In de gewenste Europese guidance zou minstens aan de orde moeten komen welke personen deel mogen nemen aan een clean room, de geoorloofde reikwijdte van pre-completion covenants, de toelaatbaarheid van marehousing-constructies en de grens tussen voorbereiding en implementatie. In de tussentijd moeten we het doen met de huidige rechtspraak en literatuur. Buitenlandse besluiten kunnen behulpzaam zijn bij het beantwoorden van complexe vragen, zoals de grens tussen voorbereidende maatregelen en implementatie. $^{122}$ Vooral de Amerikaanse literatuur is een goede bron voor lezers die meer willen weten. ${ }^{123}$

119. Speech W. Blumenthal, 'The Rhetoric of Gun-Jumping', 10 november 2005 , p. 4.

120. B. de Luca Drago en F.B.V. Morselli, 'Clarifying Gun Jumping Through Guidelines: The Brazilian Experience', JCLAP 2016, vol. 7, nr. 2, p. 130-134. In Frankrijk is een debat op gang gekomen tussen de autoriteit en de mededingingsrechtelijke advocatuur over gun-jumpingrichtsnoeren. Zie P. Guniganti, 'French enforcer to review lawyers' gunjumping guideline suggestions', GCRI 12 september 2017.

121. FTC, 'Avoiding antitrust pitfalls during pre-merger negotiations and due diligence', 20 maart 2018.

122. Zie BGH 11 november 2008, KRB 47/08 (Gruner + Jahr III) 2008 (vervanging van twee bestuurders in een joint-venture) en OLG Düsseldorf 9 december 2015, VI-Kart 1/15 (Edeka/Tengelmann) (sluiten van een gezamenlijke inkoopovereenkomst).

123. M.C. Naughton, 'Gun-Jumping and Pre-Merger Information Exchange: Counseling the Harder Questions', ANTITRUST 2006, vol. 20, nr. 3, p. 66-73; W.R. Vigdor (red.), Premerger Coordination - The Emerging Law of Gun Jumping and Information Exchange, ABA Book Publishing 2006; M.H. Morse, 'Mergers and Acquisitions: Antitrust Limitations on Conduct Before Closing', The Business Lawyer 2002, vol. 57, nr. 4, p. 1463-1486. 